[Munthe, E., \& Midthassel, U. (2002). Peer Learning Groups for Teachers: A Norwegian Innovation. New Zealand Annual Review of Education, 11, 303-316]

\section{Peer Learning Groups for Teachers: A Norwegian Innovation}

\section{ELAiNE MUNTHE AND UNNI MidTHASSEL}

\section{Abstract:}

This paper presents a method used in Norwegian schools to enhance learning and development in groups of teachers. It is a peer based mentoring method that was first introduced in the 1980s and has developed in different ways over the years. Our focus is on the uncertainty that is characteristic of teaching and schools and the consequent need for teachers to be able to get together in organized groups to dwell on topics or problems in a reflective, critical and constructive way.

$\mathrm{T}$ eaching has long been acknowledged as a many-faceted occupation involving on-the-spot decision making and little time for reflection. It is an unpredictable profession and because of its unpredictability it is also fraught with uncertainty.

Lortie (1975) ascribed the endemic uncertainty that he found among teachers in his study to the demands from society and the inability of the school system to provide a means of self-assessment or a system of rewards. Teachers were basically left to work on their own in a school characterized by presentis $\mathrm{m}^{1}$ and individualism. Their uncertainty was to a large extent related to not being sure that they could "make all their students learn" (1975, p. 132). This conception of uncertainty is echoed in Rosenholtz's work (1989). She understands uncertainty as "few well-established techniques - codified technical knowledge - to help teachers meet students' widely varying needs" (p. 4). Jones and Godfrey (1993) as well as Metz (1993) refer to uncertainty as the daily questions that teachers continually ask of themselves: "Am I doing enough?"; "Am I too lenient or too tough?"

Uncertainty will continue to be endemic to teaching because so much of teaching is unpredictable and uncontrollable. It is important to stress that the goal is not to eliminate uncertainty either (Lange \&

\section{Elaine Munthe and Unni Midthasse}

Burroughs-Lange, 1994; Munthe, 2001a, 2001b). That would mean the same as believing one has all the correct answers, being completely certain about everything. Teachers need to question their methods, they need to question how they interact with parents, whether students are learning enough, whether they are dealing with bullying in a good way, and so on. There are matters where we might even need to be more uncertain than we have been. Uncertainty is positive in that it has potential for change and for learning. Without uncertainty there would be little development. In our decision-making, uncertainty also plays a key role and should be acknowledged as such, needing to be regarded as information, not as ignorance (Funtowicz \& Ravetz, 1990). Thus, teachers need to be able to cope with uncertainty. They need to be able to deal with uncertain situations and make adequate decisions, or in other words, they need to be professionally certain in relation to professional uncertainties (Munthe, 2001a, 2001b). Being able to cope with uncertainties implies being able to answer questions or doubts with new insights. As Peter Marris (1996, p. 88) maintains: "In the face of uncertainty, room to manoeuvre may be as crucial as the resources one controls." Room to manoeuvre includes contingencies, knowing about and being able to implement and choose between several options.

Learning to cope with or master uncertainty is considered a major part of developing professionally (Schön, 1983; Eraut, 1994). Reflection over actions as well as reflection over thoughts about actions is required. This is in line with the views of Argyris \& Schön (1974) who emphasize the link between one's professional behaviour and "theory of action". A key to development and change, the authors maintain, is in the examination of the relationship between explicit "espoused theories" and the actions carried out in school, or the "theories-in-use". However, since researchers have consistently found a positive relationship between school context variables such as support, collaboration, learning possibilities and teachers' professional certainty (Rosenholtz, 1989; Munthe, 1997), we can assume that the individual's professional development is also contingent on the school s/he is employed at. The role of the principal or the governing body of the school is vital in securing the means for adequate professional development of the staff. Introducing ways to let uncertainty become fruitful rather than detrimental is therefore regarded as a school-level responsibility.

In this article we will present one method that we have worked with for nearly a decade. The Centre for Behavioural Research, where we are both employed, is a national competence centre within the field 
of social and emotional problems among children and adolescents. One of the ways that we help schools work to prevent such problems from increasing, and promote positive development among their students, is to introduce teacher mentoring or learning groups as a school-level strategy. This is a group method for teachers where they are allowed the time and opportunity to present their uncertainties and reflect on various ways of understanding them, as well as to consider various ways of coping with them.

\section{Peer Learning Groups for Teachers}

Since the 1980s, peer mentoring among teachers has been advocated in Norway as one way to enable teachers to enhance their professional development. The first to make an impact in this area were Per Lauvås, Gunnar Handal and Kirsten Hofgaard Lycke (Lauvås \& Handal, 1990, 2000; Lauvås, Lycke \& Handal, 1992). Since then, others have entered on-stage, emphasizing different aspects of mentoring, for instance a systems perspective (Gjems, 1995), and emotions (Killén, 1992; Tveiten, 1998). Our own work in this field has mainly been focused on mentoring as a method for teachers to deal with uncertainties relating to students whom they perceive as having social and/or emotional problems (Midthassel, 1997).

The learning model that has evolved over the past decade at the Centre for Behavioural Research, is to a large degree based on the example set by Lauvås, Lycke, and Handal (1992). The model has maintained the rigid structure proposed by these authors, but focuses more on time for reflection, since the "problem area" in focus has always been social and emotional problems. The model also includes a system perspective, and teachers are encouraged to ask questions that highlight relationships in the systems in question.

Which concept to use to describe the activity we have in mind is always a difficult choice when there are several possibilities. Supervision, mentoring and counselling are basically the concepts that have been used, and that we also have used in our work. However, all three concepts can imply a difference in status. A supervisor may have a higher position than the person being supervised. A mentor may be more experienced. A counsellor may have more knowledge about certain things. The key words for us are "peer", to describe that the activity takes place among equals, and "learning", to focus on the main goal of the activity. All of the teachers in the group are expected to present concerns and questions that they wish to learn more about, and all of the teachers in the group are expected to help each other think, plan and learn. This also means that members are not to be held responsible for others' actions. Each teacher is responsible for his or her own actions.

The group of about 6-8 teachers meets regularly throughout the school year, about once every month. The members form a learning community where their own knowledge, experiences and challenges are the main material. One of the persons in the group is the designated group leader and calls in and leads the meetings. If the group has decided to keep a log, this will also be the group leader's responsibility. The group leader has previously attended a three-day course to learn about peer group learning and to practise using the model. The time that is set aside for the group session is about $1 \frac{1 / 2}{2}-2$ hours.

The main group session is, however, only one of four stages in the learning process. The stages are given in Table 1 below:

\begin{tabular}{|l} 
Table 1 \\
Peer Learning Groups: A Process \\
1. \\
2.
\end{tabular}

Stage 1: Preparation

Each teacher knows when it will be his or her turn to present a topic or problem to the group. This has already been decided on at the first meeting. As an example, we can imagine Karen, a secondary school teacher who knows that it is her turn to present something to the group next month. She will spend some time thinking and planning what to present, and before the meeting she will also have written between half a page and one page about her topic to be presented to the group. This document will have a concluding question posed by Karen, and this is the question that Karen wishes to learn more about or be given the time and opportunity to think more about. Perhaps she is planning a meeting with parents and needs help to find out how to do this? Perhaps she is worried about one of the children in her class - is a girl being bullied? What can she do? Or perhaps she is uncertain about her own role as a teacher - is she too demanding of certain students? 
Stage 2: Group learning session

The purpose of the learning group is to investigate the problem or uncertainty brought forward by one of the group members ("the seeker"), to help the seeker to reflect about his or her actions, reasons and justifications with regard to the problem or uncertainty brought forward. Furthermore, the group is expected to help the seeker reflect about the actions s/he plans to take and also to find and evaluate alternative actions (See Table 2 for an overview of the eleven steps in the mentoring group session.) If the seeker wants help from someone else in the group, s/he can ask for this at the end of the session. If Karen's topic is bullying, she can ask a teacher she knows has done a lot of work in this area to help her.

\section{Stage 3: Further work}

During the third stage, the seeker works on the problem and tries to improve the situation in question or learn more about it. If the topic presented was a parent meeting, Karen will hold the meeting, carrying out some of the things she planned while in the group session. She will experience how the meeting goes, and can then assess it. If the topic presented was the girl Karen was worried about, she may have decided in the group session that she had to talk to the girl, and may have planned how to conduct this talk. During stage three, Karen would carry out this talk and gain experience from it.

\section{Stage 4: Follow-up}

The purpose of the follow-up meeting is for the seeker to report to the group the results of the work carried out. This represents a good opportunity to share experiences and assessments, providing a learning opportunity for both the seeker and the other group members. Making sure that follow-up is part of the process also puts some pressure on the seeker to actually do something. Furthermore, it provides the possibility of giving feedback to the seeker on work that has been carried out, something which is sorely missed in many schools.

\section{A Closer Look At the Group Learning Session}

The stages that we will look more closely at are stages two and four. In Table 1, follow-up is listed as stage four. However, in the learning group, the monthly meeting starts with time for follow-up of a previous problem or topic (about $20+$ minutes) if that has been agreed on, and then moves on to the presentation of a new problem or topic. In our presentation, we will follow the stages in Table 1, thus starting with stage two and the presentation of a topic or problem for the first time (See Table 2 below).

Table 2

\section{Peer Learning Groups For Teachers: The Main Session}

1. Seeker introduces the problem/topic and states clearly what s/he wishes help with.

2. Questions posed by mentors to understand the problem/topic. One question each, but several rounds are possible.

3. Mentors write what they believe the seeker wishes to learn more about

4. Mentors read their understanding aloud and Seeker comments on each. Seeker states again what $\mathrm{s} / \mathrm{he}$ wishes to focus on in this session (can be revised).

5. Mentors pose questions to enable Seeker to reflect on problem/topic from several perspectives. Questions must be open-ended and not include advice (implicit or explicit). One question each, but several rounds are possible.

6. Seeker states and reasons around goals for this problem/topic. Group leader writes goals on flip chart.

7. Seeker states and reasons on strategies/possible actions to reach these goals. Group leader writes all suggestions on the flip chart.

8. Mentors give Seeker suggestions on possible actions and also provide some reasoning. One suggestion each, but several rounds are possible.

9. Seeker explains and reasons on what $\mathrm{s} / \mathrm{he}$ wishes to do after having listened to all of the suggestions.

10. Seeker can ask for assistance from a group member.

11. Group leader thanks the Seeker for having presented this problem or topic, and gives the sheets of paper to the Seeker. Group leader asks Seeker when a follow-up session is possible and a date is set.

The setting for this process is as follows: Six to eight teachers sit in a circle or around a table so that they can all see each other. One person is the "seeker", or the teacher to present a topic/problem. One person is the group leader. The other four to six people are the "mentors" for this session. The group leader has access to a flip chart. Each member of the group has been introduced to the group learning model and has a copy of the 11 steps. 
The structure presented in Table 2 consists of four parts:

A. Presenting and understanding the problem (includes steps 1-4).

B. Reflection (step 5).

C. Possible strategies and planning (steps 6-10).

D. Follow-up (step 11).

Step One is to present a problem or "an uncertainty" to the group. The teacher will read aloud what he or she has written on the document which has been prepared. Some groups request a copy of the document in advance so the mentors can also be more prepared for their job, but this is not necessary. If a teacher chooses to distribute a document to all members in advance, the group also needs to have a routine for destroying the copies afterwards.

Step Two is for the other members to ask questions to learn more about the situation presented by the seeker. Each mentor is allowed to ask one question before passing the word to the next mentor. Questions that are asked here tend to be more technical. The mentors are interested in learning more about the factual situation before moving on to more reflective questions. In Karen's case, her colleagues might need to know how many lessons per week Karen teaches the girls, or how many friends the girl appears to have in class. The seeker answers questions as they are asked, one at a time, trying to give answers that might help the mentors understand the facts in the situation better. Two rounds of questions are usually enough, but the group leader can ask whether there are more questions after two rounds. The mentors can also say "pass" if they have nothing they wish to ask in this round.

Step Three involves individual work for the mentors and gives the seeker time to relax and think. Each mentor formulates the essence of the problem presented from the seeker in his or her own words in writing: "What is the problem which the seeker wants help with?"

Step Four is the step where one by one the mentors read their formulations made in step three aloud, and seeker listens. When all have been read, the seeker comments on the formulations and concludes by specifying the problem which s/he wants help with. This might be identical with what was said in Step One, but it might also have changed somewhat. This step can sometimes appear irrelevant, but every so often it does in fact provide the opportunity for the seeker to "get the group back on track", or to revise his or her original question, after hearing the first round of questions and the way the group members have understood the problem presented.
Step Five is when more reflective questions are asked. The mentors ask questions - answered one at a time - providing the seeker with the possibility to reflect over his or her actions so far, understanding of the problem, the various aspects of the problem and understanding of these, as well as his or her reasoning and justification. According to Handal (1991), actions, practical and theoretical reasons and the ethical justification form a practical theory that needs to be reflected upon in order to develop. This is in line with Argyris and Schön (1974) and Day (1999), among others.

To maintain the structure and prevent any of the mentors from dominating the others, each mentor is allowed to ask one question and listen to the response without interfering with what the seeker replies, before passing the word to the next person. The questions have to be open-ended to make reflection possible. Examples of such questions might be: "How did you come up with that conclusion?", "What made you change your mind?", "Why do you think she behaves this way?", "How do you think the other students react to the situation?", "How do you think this problem of yours affects your working situation?"

The group leader has to be especially aware at this time to ensure that the questions posed take into consideration various perspectives. This is especially necessary in cases where the topic is a problem that the teacher has struggled with for a long time, or has become emotionally drained over. Under these circumstances, it is difficult to see other perspectives than one's own. The mentors need to ask questions that enable the seeker to see other viewpoints. This can be to see the problem from another person's angle, but it can also be to see the problem or topic from another theoretical position. If the group is unable to provide good questions for reflection, the group leader takes a time-out to focus on this and remind the mentors to include various perspectives in their questioning. Besides helping the seeker to become aware of his or her practical theory and see the topic/problem in a more differentiated way, these questions also make it possible for the mentors to understand how the seeker reasons.

Step Six marks the transition to action or possible strategies and planning. Here the focus is on the seeker's actual action strategies for further work. The group leader asks the seeker to state his or her aims for the work. What are his or her goals? This information is helpful both for the seeker who has to focus on a future goal, and for the mentors who will be asked to give the seeker advice. The group leader writes the goals on a flip chart exactly as the seeker words them. 
Step Seven focuses on the seeker's strategies for attaining the goals. Furthermore, the seeker is asked to think through possible future strategies using his or her practical theory. The group leader writes the strategies on the flip chart as the seeker formulates them.

Step Eight is when the mentors are able to give the seeker specific advice to help further activity on the problem/uncertainty. They are each asked in turn to give one suggestion in relation to the topic, and to elaborate on why they see this suggestion as relevant, referring to their own practical theory. The group leader writes all the suggestions on the flip chart. If there are more suggestions after one round, the group leader can suggest a second round. The others should not discuss the suggestions given. They are simply given, justified and written.

This is often the step that is found most difficult and "unnatural" at first. "Why can't we give advice before?" Very often, members of a group already know what advice they want to give after Step One, but according to this model they have to wait another hour. Waiting can be difficult for a teacher who is used to action. This model emphasizes due respect for the matters raised as complex problems that need to be thought about and studied from various angles before solutions or possible strategies can be sought. It also recognizes that the seeker is the person who should find out what to do because s/he is the person who will be acting on it - not the other members.

Step Nine invites the seeker to comment on the advice given and to tell the group what s/he plans to do. Comments made should also include underlying reasoning, and thus inform the group why these preferences are being made.

Step Ten gives the seeker opportunity to ask one or two of the group mentors for support in the work, which follows this main session (stage three). It might be an advantage for the seeker to have "an involved colleague" to discuss and perhaps to work with, when trying to deal with the problem/uncertainty.

Step Eleven concerns the follow-up session. The group leader asks the seeker when s/he wants to report her further work to the group, and they agree on a date. The activities in this follow-up session are given in Table 3 , on the following page.

In the follow-up section the previous seeker is called a "reporter" and the other group members are mentors. The procedure follows through the steps in the table, in sequence. At the end, it is the responsibility of the reporter to decide what should be done, depending on the outcomes achieved.
Table 3

Peer Learning Groups for Teachers: the Follow-up Session

1. The reporter reports on what $\mathrm{s} /$ he has done with the problem and what has happened since the group session when it was the topic.

2. The reporter shares his or her reflections and feelings with regard to the actions performed.

3. The mentors ask questions to get a deeper understanding of the situation described by the reporter. Each mentor is allowed to ask one question and listen to the response before passing the word to the next mentor.

4. The reporter decides what will be done next. There are several possibilities; the problem is solved, s/he will continue to work on it the way s/he already is, or the problem needs to be worked on differently and $\mathrm{s} / \mathrm{he}$ asks to raise the problem in a main session again.

\section{Introducing Peer Learning Groups in Schools}

An important part of the course we offer deals both with theories of change, and with research on change in schools (Fullan, 1991, 1993; Hopkins, 1996; Midthassel, Bru \& Idsöe, 2000; Midthassel \& Bru, 2001; Rogers, 1995; Sarason, 1996; Senge, 1992; Senge et al., 2000; Stoll, 1998). Introducing peer mentoring groups can be characterized as a revolutionary action in some schools, or simply another step in an existing programme of professional development for others. We still find that being uncertain is considered "unprofessional" in many schools. In such schools, teachers feel the need to hide uncertainties from colleagues. Uncertainty has been found to correlate positively with routine behaviour (Rosenholtz 1989), and the schools in question where uncertainty is hidden, tend to be the traditional schools where little innovation occurs.

Through the years that we have been involved with introducing peer learning groups, we have encountered some key questions raised by the schools or by group leaders who have attended our courses or worked with us during the change process. We believe that many of the questions will prove to be general questions that are of relevance also for schools in other countries. An overview of some of these questions is given below. None of the questions have easy answers, just as introducing peer learning groups in a school is no easy route to a "quick fix". 
Table 4

Questions to discuss when deliberating whether and how to introduce peer group learning in a school

- Is this relevant for us? Do we need this kind of collaborative mentoring model? Why? How? For whom? For what?

- Should peer learning be voluntary or mandatory?

- What kind of implementation strategy should we have? Who - when where - how - why?

- How can we develop a strategy? Who should be involved?

- Should we introduce peer learning on a school level or let one group start?

- How do we introduce the topic to the teachers? In groups or plenary?

- Where do we find the time for this?

- How do we put together groups? Same grade level? Different grade levels? Within school or between schools? Existing teams or new teams? Why?

- Who should be group leaders? Should all members of a group be group leaders eventually?

- Should the principal be a member of a group if the principal also teaches?

- How do we make sure that what goes on in the groups remains within the group and is not discussed openly afterwards?

- How do we evaluate this? When?

While some schools organize learning groups of teachers from different grade levels within the school, others prefer to establish groups within the same level across schools. There seem to be advantages and disadvantages with both forms. Within-school groups provide sharing and learning in the same school environment (Midthassel \& Bru, 2001). Besides the effect this could have on the learning and development of the teachers involved, it might also have a positive effect of creating a culture for learning (Schein, 1992; Senge, 2000 ). But an obvious disadvantage of the within-school organisation is that the teachers will lack the perspective and ideas brought in by someone outside the school.

We have met several schools where the teachers report having stopped using peer learning groups, for various reasons. This has to be expected of course. Peer learning groups are not designed to be the answer to all our troubles. The method is one way amongst several that schools can use. What we do experience, however, when inquiring further about how the learning groups were used, is that there is often a flaw in either the organisational aspects or the quality of the mentoring that took place. What role has the principal played during the implementation of the groups or in the ongoing learning process? Is time set aside on the teachers' plans? How are the groups followed up, and how is the quality assessed? Teacher collaboration can also reinforce habits which are not well informed (Little, 1990), and group learning may simply be a vehicle to maintain the status quo if it is not carried out in a critical reflective way.

\section{Note}

1. Presentism is a word that Dan Lortie uses to describe an aspect of teaching, and since the publication of his book in 1975, it has been used quite frequently to indicate that career rewards in teaching are present-oriented rather than future-oriented. "Most teachers will therefore emphasize rewards they can earn in the present; this propensity affects the kinds of rewards which will matter to them", Lortie explains (1975, p. 101)

\section{References}

Argyris, C., \& Schön, D. A. (1974). Theory in practice. San Francisco: Jossey-Bass.

Day, C. (1999). Developing teachers: The challenges of lifelong learning. London: Falmer Press.

Eraut, M. (1994). Developing professional knowledge and competence. London: Routledge/Falmer Press.

Fullan, M. (1993). Change forces. London: Falmer Press.

Fullan, M. (1991). The new meaning of educational change. London: Cassell.

Funtowicz, S. O., \& Ravetz, J. R. (1990). Uncertainty and quality in science for policy. Dordrecht, the Netherlands: Kluwer Academic Publishers Group.

Gjems, L. (1995). Veiledning i profesjonsgrupper. Oslo: Universitetsforlaget.

Handal, G. (1991). Collective time - collective practice? The Curriculum Journal, 2(3), 317-333.

Hopkins, D. (1996). Towards a theory for school improvement. In J. Gray, D. Reynolds, C. Fitz-Gibbon \& D. Jesson (Eds.), Merging 
traditions: The future of research on school effectiveness and school improvement. London: Cassell.

Jones, G., \& Godfrey, G. (1993). Points of entry: A cooperating teacher learns by seeing the lessons in the stories. In Clandinen et al. (Eds.), Learning to teach: Teaching to learn. New York: Teachers College Press.

Killen, K. (1992). Faglig veiledning - et tverrfaglig perspektiv. Oslo: Universitetsforlaget.

Lange, J., \& Burroughs-Lange, S. (1994). Professional uncertainty and professional growth: A case study of experienced teachers. Teaching $\mathcal{E}$ Teacher Education, 10(6), 617-631.

Lauvås, P., \& Handal, G. (1990/2000). Veiledning og praktisk yrkesteori. Oslo: Cappelen.

Lauvås, P., Lycke, K., \& Handal, G. (1992). Kollegaveiledning. Oslo: Cappelen.

Little, J. W. (1990). The persistence of privacy: Autonomy and initiative in teachers' professional relations. Teachers College Record, 91, 509-536.

Lortie, D. (1975). Schoolteacher: A sociological study. Chicago: University of Chicago Press.

Marris, P. (1996). The politics of uncertainty. London: Routledge.

Metz, M. H. (1993). Teachers' ultimate dependence on their students. In J. W. Little \& M. W. Mclaughlin (Eds.), Teachers' work. New York: Teachers College Press.

Midthassel, U. V. (1997). Veiledning som arbeidsmaate for å möte utfordringer $i$ skolen. Stavanger: Stavanger University College.

Midthassel, U. V., Bru, E., \& Idsøe, T. (2000). The principal's role in promoting school development activity in Norwegian compulsory schools. School Leadership and Management, 20(2), 147-160.

Midthassel, U., \& Bru, E. (2001). Predictors and gains of teacher involvement in an improvement project on classroom management. Experiences from a Norwegian project in two compulsory schools. Educational Psychology, 21(3), 229-242.

Munthe, E. (1997). Teacher collaboration - A source of greater perceived certainty? Oslo: University of Oslo.

Munthe, E. (2001a). Measuring teacher certainty. Scandinavian Journal of Educational Research, 45(2), 167-181.
Munthe, E. (2001b). How (un)certain are teachers, what are they (un)certain about, and how does this relate to age, gender, experience, education and school type? European Journal of Teacher Education, 24(3), pp. 355-368.

Rogers, E. (1995). The diffusion of innovation. New York: Free Press.

Rosenholtz, S. J. (1989). Teachers' workplace. New York: Teachers College Press.

Sarason, S. B. (1996). Revisiting the culture of the school and the problem of change. New York: Teachers College Press.

Schein, E. (1992). Organizational culture and leadership (2nd ed.). San Francisco: Jossey-Bass Publishers.

Schön, D. (1983). The reflective practitioner. Aldershot: Ashgate Arena.

Senge, P. (1992). The fifth discipline. London: Century Books.

Senge, P., Cambron-McCabe, N., Lucas,T., Smith, B., Dutton, J. \& Kleiner, A. (2000). Schools that learn. London: Nicholas Brealey Publishing.

Stoll, L. (1998). Supporting school improvement. Paper presented at the first follow-up conference on the OECD activity "Combating Failure at School", Christchurch, New Zealand.

Tveiten, S. (1998). Veiledning - mer enn ord. Bergen: Fagbokforlaget.

\section{The authors}

Unni V. Midthassel is associate professor at the Centre for Behavioural Research, where she has been employed since 1994. Her main research interests are in the field of school development and change. She is actively involved in the development of, and ongoing work in, a national three-year program intended to engage school psychologists in more systemic work with schools (Samtak, 2000-2002).

Elaine Munthe is assistant professor at the Centre for Behavioural Research where she has been employed since 1995. Her main research interests are in the field of teacher development and change. She is currently funded by the Norwegian Research Council to study the development of teachers' professional certainty/uncertainty in a longitudinal research project. 